\title{
THE PERCENTAGE OF ACTIVE E ROSETTE FORMING CELLS AFTER INCUBATION OF PIG LYMPHOCYTES IN XENOGENEIC SERA
}

\author{
Z. KNOTEK, P. VOJTIŠK, P. HOǨ́N and Petra MLÁDKOVÁ \\ Department of Animal Breeding and Genetics, \\ University of Veterinary and Pharmaceutical Sciences, 61242 Brno
}

Received November 5, 1992

\begin{abstract}
Knotek Z., Vojtíšek, P., Hořín, P. and Petra Mládková: The Percentage of Active E Rosette Forming Cells After Incubation of Pig Lymphocytes in Xenogeneic Sera. Acta vet. Brno, 62, 1993: 33-37.

The detection of Early Pregnancy Factor (EPF) is not feasible in some species that have only limited ability to form spontaneous E rosettes. Since EPF is not species specific, a suitable model for its detection in sera of these species based on the capacity of some other species to form active spontaneous $\mathrm{E}$ rosettes is arched. We have investigated the influence of incubating pig lymphocytes in sera of mice, rabbits, dogs, sheep, horses, cows, women and sows (control) upon the percentage of active $\mathrm{E}$ rosette forming cells (ERFCs). The incubation of pig lymphocytes in xenogeneic sera was not followed by any significant alterations in the percentage of ERFCs, but this parameter was changed significantly $(27.15 \pm 1.31$ versus $39.52 \pm$ $\pm 4.78 \%, \mathrm{p}<0.01)$ by increasing the lymphocytes/sheep red blood cells ratio from $1: 10$ to $1: 30$.
\end{abstract}

Pig lymphocytes, pregnancy serum factor, early pregnancy factor

One of the earliest pregnancy signals that is detected during the preimplantation period is the Early Pregnancy Factor (EPF, Morton et al. 1977; Morton et al. 1979; Smart et al. 1981). The detection of EPF presence in pregnancy serum, pregnancy urine or supernatant from embryo culture system (Morton et al. 1977; Clarke et al. 1980; Cavanagh 1984; Roberts et al. 1985; Sueoka et al. 1986; $\mathrm{Nahhas}$ et al. 1988) is based on the rosette inhibition test (Bach et al. 1969; Morton et al. 1976; Morton et al. 1983), i. e. on the formation rate of spontaneous active $\mathbf{E}$ rosettes in the presence of antilymphocyte serum and complement. Some species have only poor ability to form spontaneous $\mathrm{E}$ rosettes (Binns 1978). Different methods of enhancing this reaction were shown to have negative influence upon EPF detection (Morton et al. 1982). Thus, the detection of EPF is not feasible in some species (Tiemann and Klima 1985). Since EPF is not species specific, a suitable model for its detection in sera of some species based on the capacity of other species to form active $\mathbf{E}$ rosettes was searched (Rolfe et al. 1984, Chen et al. 1985, Clarke et al. 1987). The pig is one of the species in which the detection of EPF is feasible from this point of view (Morton et al. 1983, Koch 1983, Knotek 1991). In an attempt to verify the feasibility of using pig lymphocytes for these purposes, we investigated the influence of incubating pig lymphocytes in xenogeneic sera upon the percentage of active $E$ rosette forming cells (ERFCs).

\section{Materials and Methods}

The effect of sera from non-pregnant healthy adult mice, rabbits, dogs, sheep, horses, cows, women and sows (control) was investigated. The preparation of pig peripheral blood lymphocytes suspension and sheep red blood cells suspension (SRBCs) were made according to Knotek (1990). Briefly, pig lymphocytes $\left(10^{7}\right)$ were incubated in $0.2 \mathrm{ml}$ of inactivated sera (diluted $1: 2$ in Hanks solution) in $37^{\circ} \mathrm{C}$ for 30 minutes. After two washings pig lymphocytes $\left(10^{6}\right)$ were mixed 
with SRBCs $\left(10^{7}\right)$ and Hanks solution $(0.1+0.1+0.1 \mathrm{ml})$ and tubes were centrifuged at $125 \mathrm{~g}$ for 5 minutes. Pellets were gently resuspended and the percentage of ERFCs form at least 20 lymphocytes was immediately counted in haemocytometric chamber (Meopta Praha, Czechoslovakia). The viability of lymphocytes as tested with Trypan blue exclusion was more than $95 \%$. All steps were performed in polystyrene tubes (KOH-I-NOOR, Czechoslovakia). Hanks balanced salt solution without $\mathrm{Ca}^{2+}$ and $\mathrm{Mg}^{2+}$ was generous gift of Dr. F. Klima (Academy of Sciences, Berlin). Data were statistically analysed using a test for comparison of relative frequencies.

\section{Results}

The incubation of pig lymphocytes in xenogeneic sera was not followed by any significant alterations in the percentage of ERFCs (Table 1, Table 2). The different percentage of ERFCs presented in Table 1 and Table $2(P<0,01)$ resulted from two different lymphocytes /SRBCs ratios (1:10 and 1:30).

\section{Discussion}

The percentage of ERFCs was not altered after incubating pig peripheral blood lymphocytes in xenogeneic sera. It seems that no non-specific inhibition of $\mathrm{E}$ rosette formation occurs and thus it is feasible to verify whether this system is able to detect EPF activity in the species tested. Morton et al. (1982) warned that any task of enhancing the rosette formation had negative influence upon EPF detection. In the present study, the xenogeneic sera were present in the test system only during the incubation period and they were not present during the

Table 1

\begin{tabular}{|c|c|c|c|c|}
\hline \multirow{2}{*}{ Sera } & \multicolumn{4}{|c|}{ Percentage of E-Rosettes } \\
\hline & I. & II. & III. & mean $\pm S D$ \\
\hline $\begin{array}{l}\text { Sow } \\
\text { Sow } \\
\text { Sow }\end{array}$ & $\begin{array}{l}25.74 \\
29.31 \\
28.70\end{array}$ & $\begin{array}{l}27.12 \\
27.33 \\
25.01\end{array}$ & $\begin{array}{l}26.88 \\
26.92 \\
27.33\end{array}$ & $27.15 \pm 1.31^{\mathrm{a}}$ \\
\hline $\begin{array}{l}\text { Woman } \\
\text { Woman } \\
\text { Woman } \\
\text { Woman }\end{array}$ & $\begin{array}{l}27.27 \\
28.00 \\
32.47 \\
28.85\end{array}$ & $\begin{array}{l}26.47 \\
27.35 \\
33.53 \\
31.82\end{array}$ & $\begin{array}{l}31.31 \\
27.34 \\
26.47 \\
24.79\end{array}$ & $28.81 \pm 2.79^{a}$ \\
\hline
\end{tabular}

a $P>0.01$, pig PBL : SRBC, $1: 10$

Table 2

\begin{tabular}{|c|c|c|}
\hline Sera & $\underset{\mathrm{n}}{\text { Samples }}$ & $\begin{array}{c}\text { Percentage of E-Rosettes } \\
\text { mean } \pm \text { SD }\end{array}$ \\
\hline $\begin{array}{l}\text { Mice } \\
\text { Rabbits } \\
\text { Dogs } \\
\text { Sheep } \\
\text { Horses } \\
\text { Cows } \\
\text { Sows }\end{array}$ & $\begin{array}{l}9 \\
9 \\
9 \\
9 \\
9 \\
9 \\
9\end{array}$ & $\begin{array}{l}36.60 \pm 1.54^{\mathrm{a}} \\
37.71 \pm 3.82^{\mathrm{a}} \\
38.28 \pm 3.52^{\mathrm{a}} \\
40.80 \pm 3.17^{\mathrm{a}} \\
39.11 \pm 2.82^{\mathrm{a}} \\
37.73 \pm 2.26^{\mathrm{a}} \\
39.52 \pm 4,78^{\mathrm{a}}\end{array}$ \\
\hline
\end{tabular}

$a_{P}>0.01$, pig PBL : SRBC, $1: 30$ 
actual rosette reaction as was the case of the fetal calf serum in the system described by Jarošková and Kovářů 1978). The differences found in the percentage of ERFCs were given only by different lymphocytes /SRBCs ratios as described also by Smith et al. (1975) and Woody and Sell (1975).

$\mathrm{EPF}$ in some animal species was detected by using human lymphocytes (Sueoka et al. 1988; Kavkasidze 1989). Sera from some species had to be fractioned before the EPF detection by the rosette inhibition test (Klima et al. 1989). We observed EPF activity in a low molecular fraction of pig pregnancy serum (Knotek et al. 1989). It remains to be tested whether a similar treatment could also improve the detection of EPF in sera of some other species by the use of pig peripheral blood lymphocytes in the rosette inhibition test. The presence of an EPF-active polypeptide in sera even of some exotic species has been recently determined by Schadow et al. (1992).

\section{Procento buněk tvořících aktivní $E$ rozety po inkubaci lymfocytů prasat $\mathrm{v}$ xenogenních sérech}

Stanovení faktoru časné gravidity (EPF) činí potíže u živočišných druhů, které mají omezenou schopnost tvořit spontánni $\mathrm{E}$ rozety. Jelikož EPF není druhově specifický, je hledán vhodný model pro jeho stanovení v séru těchto druhů, jenž by byl založen na schopnosti jiných zviŕat tvořit aktivní spontánní $\mathrm{E}$ rozety. Sledovali jsme vliv inkubace prasečích lymfocytů v sérech myší, králíků, psů, ovcí, koní, krav, žen a prasnic (kontrola) na procento buněk tvořících aktivní $\mathrm{E}$ rozety. Inkubace prasečích lymfocytů $\mathrm{v}$ xenogenních sérech nevedla $\mathrm{k}$ výrazným změnám procenta těchto buněk, avšak tento parametr byl průkazně změněn $(27,15 \pm 1,31$ oproti $39,52 \pm 4,78 \%, p<0,01)$ zvýšením poměru lymfocyty/ ovči erytrocyty $z 1: 10$ na $1: 30$.

\section{Процент активных Е-розеток после инкүбации лимфоцитов поросят В ксеногенных сыворотках}

Определение фактора ранней беременности [ЕРF] встречается с затруднениями у видов животных, отличающихся ограниченной способностью образования спонтанных Е-розеток. Так как Е чается специфичностью по видам, проводили исследования подходящей модели ее определения в сыворотке данных видов, основанной на способности других животных к сосзданию активных спонтанных Е-розеток. Проводили исследования влияния инкубации лимфоцитов поросят в сыворотках мышей, кроликов, собак, овец, пошадей, коров, женщин и свиноматок (контрольная группа) на процент клеток, образующих активные Е-розетки. Инкубация лимфоцитов поросят в ксеногенных сыворотках не вылилась в сүщественные изменения процента данных клеток, однако упомянутый параметр отличался сүщественными изменениями $(27,15 \pm 1,31$ по сравнению с $39,52 \pm 4,78 \%$, $\mathrm{p}<0,01)$ увеличением соотношения лимфоциты / эритроциты овец из $1: 10$ до $1: 30$. 


\section{References}

BACH, J. F.-DORMONT, J.-DARDENNE, M.-BALNER, H.: In vitro rosette inhibition by anti-human ALS. Transplantation, 8, 1969: 265-280

BINNS, R. M.: Sheep erythrocyte rosettes in pigs, sheep, cattle and goats demonstrated in the presence of dextran. J. Immunol. Methods, 21, 1978: 197-210

CAVANAGH, A. C.: Production in vitro of mouse early pregnancy factor and purification to homogeneity. J. Reprod. Fert., 71, 1984: 581-592

CHEN, C. -JONES, W. R.-BASTIN, F.-FORDE, C.: Monitoring embryos after in vitro fertilization using early pregnancy factor. Annals New York Academy of Sciences, 1985, 420 to 428

CLARKE, F. M.-MORTON, H.-ROLFE, B. E.-CLUNIE, G. J. A.: Partial characterisation of early pregnancy factor in sheep. J. Reprod. Immunol., 2, 1980: 151-162

CLARKE, F. M.-WILSON, S.-MCCARTHY, R.-PERKINS, T.-OROZCO, C.: Early pregnancy factor: large scale isolation of rosette inhibition test - active polypeptides from ovine placental extracts. J. Reprod. Immunol., 10, 1987: 133-156

JAROŠKOVA, L.-KOVǍ Ů, F.: Identification of $T$ and $B$ lymphocytes in pigs by combined E-rosette test and surface Ig labelling. J. Immunol. Methods, 22, 1978: 253-261

KAVKASIDZE, G. A.: The study of EPF species specifity. J. Reprod. Immunol. Suppl., 1989: 208

KLIMA, F. -TIEMANN, U.-KATZWINKEL, S.-PITRA, C.-KAUFFOLD, P.: Suppression of $T$ cell activity by early pregnancy associated maternal serum factors in cattle. $J$. Reprod. Immunol. Suppl., 1989: 78

KNOTEK, Z.: Demonstration of Early Pregnancy Factor in Gilts During the Reproductive Cycle. Acta vet. Brno, 59, 1990: 35-40

KNOTEK, Z.: Modifications of the $\mathrm{E}$ rosette test in pigs and their practical use in clinical immunology. PhD Thesis, 1991

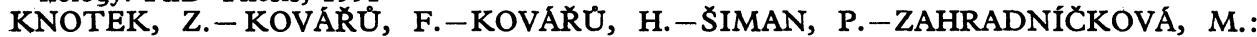
EPF and some immunoregulatory properties of gilt's pregnancy sera. J. Reprod. Immunol. Suppl., 1989: 78

KOCH, E.: Early pregnancy factor-Aktivitäten Beim Schwein. Thesis, 1983

MORTON, H. - HEGH, V.-CLUNIE, G. J. A.: Studies of the rosette inhibition test in pregnant mice: evidence of immunosuppression? Prov. R. Soc. B, 193, 1976: 413-419

MORTON, H.-ROLFE, B. E.-CLUNIE, G. J. A.-ANDERSON, M. J.-MORRISON, J.: An early pregnancy factor detected in human serum by the rosette inhibition test. Lancet, 1, 1977: 391-397

MORTON, H.-NANCARROW, C. D.-SCARAMUZZI, R. J.-EVISON, B. M.-CLUNIE, G. J. A.: Detection of early pregnancy in sheep by the rosette inhibition test. J. Reprod., Fert., 55, 1979: 75-80

MORTON, H.-TINNEBERG, H. R.-ROLFE, B. E.-WOLF, M.-METTLER, L.: Rosette inhibition test: a multicenter investigation of early pregnancy factor in humans.J. Reprod. Im nunol., 4, 1982: 251-261

MORTON, H.-MORTON, D. J.-ELLENDORFF, F.: The appearance and characteristics of early pregnancy factor in the pig. J. Reprod. Fert., 68, 1983: 437-446

NAHHAS, F.-BLUMENFELD, Z.-BRANDES, J. M.: Early pregnancy factor in human sera, urine and embryo culture medium in patients undergoing IVF-ET. Amer. J. Reprod. Im nunol. Microbiol., 16, 1988: 4

RO3ERTS, T. K.-PRICE, R.-SMART, Y. C.-STEVENSON, K.-TASEVSKI, V.: Early pregnancy factor of human urine. In: Early pregnancy factors. Edd.: Ellendorff, F.Kozh, E.; Ithaza (USA) Perinatology Press, 1985: 191-193

ROLFE, B. E.-CAVANAGH, A. C.-FORDE, C.-BASTIN, F.-CHEN, C.-MORTON, H.: Modified rosette inhibition test with mouse lymphocytes for detection of early pregnancy in hinan pregnancy serum. I. Immunol. Methods, 70, 1984: 1-11

SCHADOW, D. - KLIMA, F. - SCHRODER, H. D. - PITRA, C.: Detection of bovine Early Pregnancy Factor (EPF) active polypeptide in zoo animals. EOS-J. Immunol. Immuno harmi:sl., 12, 1932: 135

SMART, Y. C.-ROBBERTS, T. K.-CLANCY, R. L.-CRIPPS, A. W.: Early pregnancy fazt)r: its role in man nalian reproduction - research review. Fert. Steril., 35, 1981: 397-401

SMITH, R.-KERMAN, R.-EZDINLI, E.-STEFANI, S.: A modified assay for the deteztion of human adult active rosette forming lymphocytes. J. Immunol. Methods, 8, 1975: $175-181$

SUEOKA, K. - ITO, K. - KAKU, S. - NATORI, M. - MORISADA, M. - KOBAYASHI, K. -IIZUKA, R. - YOSHIMURA, S.-ODA, T.-SHIINA, M.-OONO, T.: Investigation on 
the immunological activities and releasing mechanisms of early pregnancy factor. Acta obstet. gynaec. Jap., 8, 1986: $1350-1351$

SUEOKA, K.-DHARMARAJAN, A. M.-MICHAEL, E.-ATLAS, S. J.-WALLACH, E. E.: Detection of early pregnancy factor (EPF) using the rabbit ovary and oviduct perfused in vitro. J. Reprod. Fert., 84, 1988: 325-331

TIEMANN, U.-KLIMA, F.: Use of rosette inhibition test for studies into verification of early pregnancy factor in swine and cattle. Mh. Vet.-Med., 40, 1985: 739-743

WOODY, J. N.--SELL, S. K.: Characteristics of the active rosette test. I. Technical considerations of the test and comment. J. Immunol. Methods, 8, 1975: 331-338 